\title{
E-commerce for the Development of Small Medium Enterprises
}

\author{
I Budiarti ${ }^{*}$, A M Akbar ${ }^{2}$ \\ ${ }^{1}$ Departemen Manajemen, Universitas Komputer Indonesia, Indonesia \\ 2Departemen Akuntansi, Universitas Komputer Indonesia, Indonesia \\ Email: *isniar.budiarti@email.unikom.ac.id
}

\begin{abstract}
This study aims to determine the perceived influence of the existence of ecommerce for SMEs and how the development of Small and Medium Enterprises (SMEs) businesses towards e-commerce. This study used descriptive method and literature review with interviews, reading, and quoting. After conducting research on SMEs, it had been proven that with e-commerce, SMEs had become more advanced and increasingly developed. The results of this study were technological advances can be utilized by SMEs to market and develop their business through e-commerce so that many product or service innovations are created.
\end{abstract}

\section{Introduction}

Progress in digitalization is very viral at retailers. The growth of e-commerce trend leads to customer demand, but it decreased interest and income of physical stores. Consumers have different tastes and shopping decisions which online retails will provide it. They can offer various alternatives and also attractive value proportions with a variety of products, convenient shopping processes and special solutions. Instead of offering to the target, it is better to focus on consumer access when making decisions. Even if consumers are in the store, they can also visit online websites too. To stay competitive, offline retails have linked up with their online retailers using digital technology [1]. Transacting through electronic networks such as the internet has many advantages namely convenient, low cost, wider reach and more market choices both for traders and customers. Traders who have transactions have the desire to authenticate sales, authorize sales, confirm sales, ensure there are no sales rejections, ensure payments, and control anonymity. Likewise, buyers have a desire to control sales authentication, sales integrity, bad sales guarantees, sales confirmation, privacy, and anonymity [2].

E-commerce provides opportunities for all groups in both developing and developed countries. In developed countries, the benefits will be concentrated in the short term, but developing countries will have more benefits. For developing countries with lack of infrastructure, they require the full benefit of the internet. But in the long run, developing countries must go through several stages in the development of information technology that must be passed by developed countries [3]. Technological advances have helped many fields 


\section{International Journal of Research and Applied Technology}

1(1)(2021) 239-243

Journal homepage: https://ojs.unikom.ac.id/index.php/injuratech

of business both locally and internationally. Nearly all over the world, people use the internet for various activities, ranging from learning to buying products online. The internet has affected almost all businesses starting from advertising to run functions and produce products. E-commerce can provide benefits for consumers by providing lower prices and also reduce competition [4]. E-commerce emerged with the fastest growing sector in the world market share in recent years. Companies continue to expand their activities in e-commerce and also consumers increase dramatically in the number of purchases made online. E-commerce currently plays an important role of trade as a whole, and will continue to develop along with the advancement of technology in the next few years. Finally, the growth of e-commerce will have an impact on a country's economy [5]. Advanced electronic receipts have gained openness as an efficient business-to-business model and also business to customer exchange. E-commerce technology includes computer-based solutions that support electronic exchange for personal and business use. E-commerce and internet include information search, buying, selling and others. Retails can use e-commerce and the internet as a business model. Commercial internet users have increased rapidly and retails can make use of them [6]. The development of information technology is now reaching all aspects of human life. Information technology makes things easier and cheaper. The role of information technology (IT) in business is also getting stronger, this is indicated by the activeness of large multinational companies to use the internet as means of marketing their products. The use of the internet and the world wide web (WWW) for companies today is very necessary. Every company that wants to expand its marketing reach must have a website, which is a vehicle for promotion and transactions for the company [7]. Awareness, sales, and loyalty are good targets for online retailers to be highly developed in the US, in the context of total online retail sales accounting for $9.9 \%$ in the fourth quarter of 2018 . This goes beyond all well-known physical store closures in the US and is also called the death of physical retail. There is something significant by combining strategies that have been tried and tested with modern and digital solutions [8]. The rapid progress of communication and information technology not only affects the sophistication of the technology, but also the lifestyle and the amount of human consumption of the technology. Human needs for access to information via the internet, intranet, or extranet are increasing, along with increasingly sophisticated technology. It also resulted in an increase in business opportunities using technological sophistication $[9,10]$.

The purpose of this study to discover the use of e-commerce and analyze the role of ecommerce in improving the economy of micro, small and medium enterprises (SMEs). The use of computers in marketing and sales in recent years is growing rapidly. The method used in this research was descriptive method and literature review by interviewing, reading, and quoting from various sources.

\section{Method}

This research used descriptive-qualitative method and literature review by interviewing several SMEs. Descriptive-qualitative method is to determine characteristics and behaviour of SMEs with data collection from previous study about this research object.

\section{Results and Discussion}

E-commerce was a type of electronic business mechanism that focused on individual-based business transactions using the internet (digital network-based technology) as a medium for exchanging goods or services between two institutions (business to business) and direct consumers (business to consumer). 


\section{International Journal of Research and Applied Technology}

1(1)(2021) 239-243

Journal homepage: https://ojs.unikom.ac.id/index.php/injuratech

Over the past two decades, e-commerce had provided an easy way for buyers and sellers to transact online. E-commerce was the activity of buying or selling goods, services, or information through electronic networks. Transactions negotiated electronically after an agreement had been reached and the ownership of the goods or rights were transferred at the specified price [7].

Small and Medium Enterprises (SMEs) according to Law No. 20 of 2008 concerning Micro, Small and Medium Enterprises (SMEs), small businesses are productive economic businesses that are independent, carried out by individuals/business entities that are not subsidiaries/not a branch of the company that is owned, controlled, or become a good part directly or indirectly from medium or large businesses that meet the criteria: (a) Rp. 50 million<Assets $\leq$ Rp. 500 million, (b) Rp. 300 million <Turnover $\leq$ Rp. 2.5 billion. The e-commerce industry had a positive impact on Indonesia's employment with an estimated 4 million workers connected to this ecosystem. In 2022, Indonesia's e-commerce market growth could reach around 26 million workers or $20 \%$ of the Indonesian workforce. One of these new jobs was existing jobs that were being updated by e-commerce developments, such as SMEs managers moving from offline to online businesses.

The inclusion of SMEs in e-commerce could increase Indonesia's economic growth because it was one of the ways that SMEs could market their products in addition to expanding market access. Micro, Small and Medium Enterprises (SMEs) were required to be part of the global community by utilizing information technology through e-commerce. If they did not keep abreast of information technology developments, they would be left far behind and lose in competition. SMEs must carry out various innovations in creating high quality products and can be marketed through e-commerce. Automatically, high quality products would encourage consumers to buy products through e-commerce and use electronic payments which became a habit and could improve the economy for SMEs. Shopee was one of the online stores in Indonesia that came with a complete product concept and also the convenience of online shopping for delivery (See Figure 1).

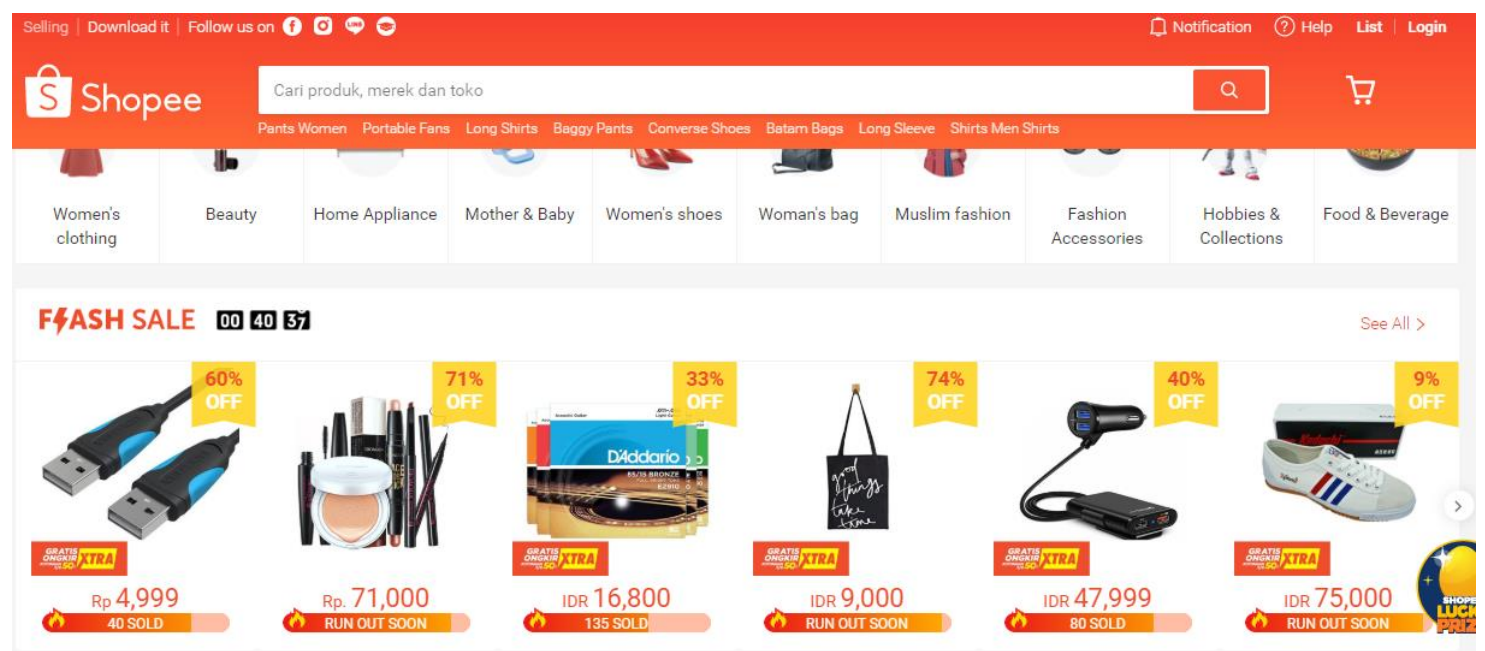

Figure 1. Shopee as the Most Used E-commerce

Many SMEs chose Shopee as their e-commerce. In addition, the majority on Shopee were SMEs. This proved that e-commerce is a medium or medium for SMEs to be able to compete with non-SMEs. Shopee had also become the place to sell through marketplace for free, so that 


\section{International Journal of Research and Applied Technology}

1(1)(2021) 239-243

Journal homepage: https://ojs.unikom.ac.id/index.php/injuratech

sellers could offer competitive prices. SMEs profits also affected by the presence of Shopee by ten times. In addition, the program presented by Shopee such as FlashSales really helped to attract consumer interest, so that it could add value to Shopee users either as sellers or consumers. The advantages of online shopping at Shopee were various available products, many discounts offered, free shipping programs, fast and most attractive processes namely COD or Cash on Delivery programs. The drawbacks were the COD had not implemented in remote areas yet and the packaging were untidy.

Tokopedia came as an innovative new e-commerce that carried the concept of various online stores in Indonesia. All trading activities and transactions processing had security guarantee. This concept was expected to create a form of online mall that initiated and coordinated number of e-commerce transactions (See Figure 2).

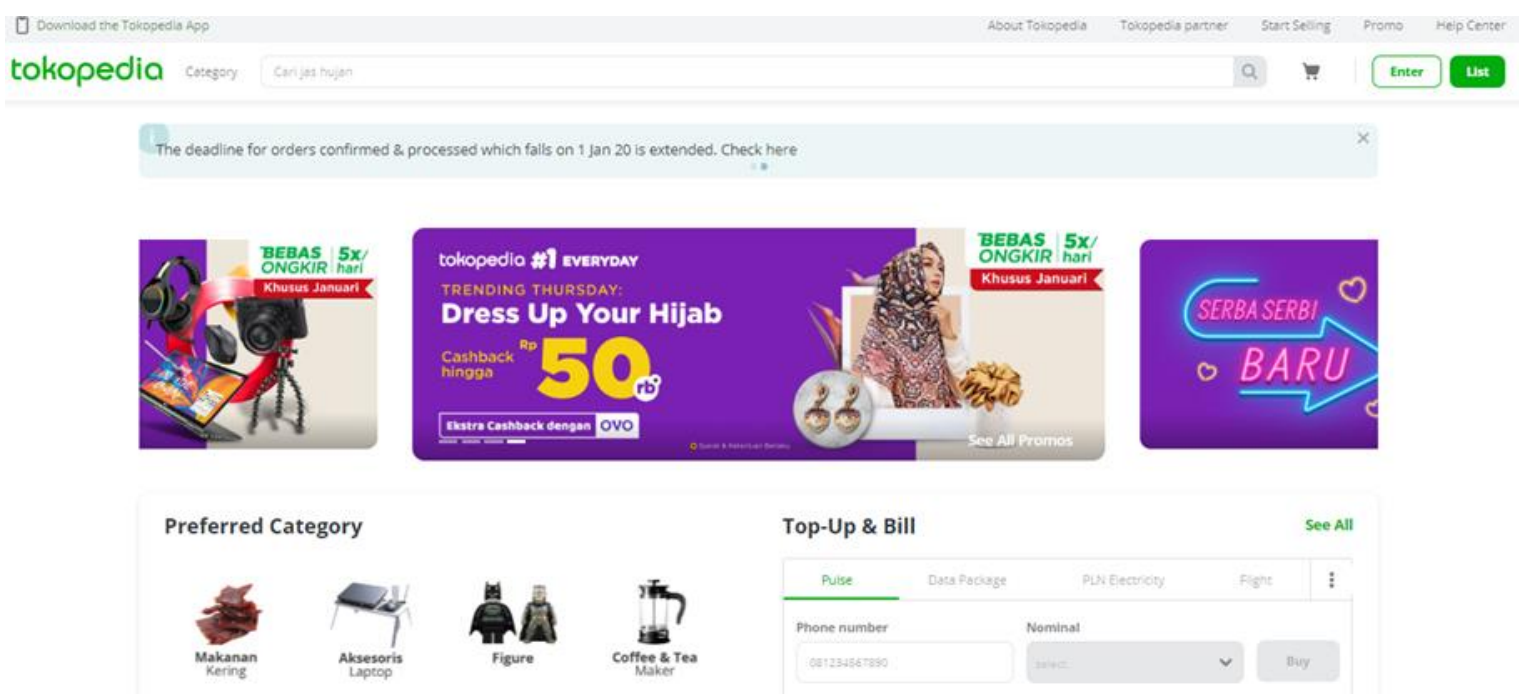

Figure 2. Tokopedia as the Most Used E-commerce

Website appearance was important with the dominance of green that seemed fresh and simple, fast page load, minimalist, and informative feature, and various menu categories. The weaknesses were that both the website and the application had errors such as late notifications and unavailable options.

\section{Conclusion}

The relationship between the SMEs and e-commerce in this global era cannot be separated. Thus, technological advances can be utilized by SMEs to market and develop their business through e-commerce so that many product or service innovations are created. With the advancement of technology, the business has increasingly developed especially products that are easily marketed. In addition, the transactions become effective and efficient and affect the SMEs profits positively.

\section{Acknowledgement}

The authors would like to thank the Rector of Universitas Komputer Indonesia (UNIKOM) and Dean of the Faculty of Economics and Business who had given the opportunity to conduct this research. 
International Journal of Research and Applied Technology

$1(1)(2021) 239-243$

Journal homepage: https://ojs.unikom.ac.id/index.php/injuratech

\section{References}

[1] Linzbach, P., Inman, J. J., \& Nikolova, H. 2019. E-Commerce in a physical store: which retailing technologies add real value? NIM Marketing Intelligence Review, 11(1), pp. 42-47.

[2] Kim, Y., \& Peterson, R. A. 2017. A Meta-analysis of Online Trust Relationships in Ecommerce. Journal of Interactive Marketing, 38, pp. 44-54.

[3] Terzi, Nuray. "The impact of e-commerce on international trade and employment." Procedia-Social and Behavioral Sciences 24. 2011: pp. 745-753.

[4] Chang, H. H., Wang, Y. H., \& Yang, W. Y. 2009. The impact of e-service quality, customer satisfaction and loyalty on e-marketing: Moderating effect of perceived value. Total Quality Management, 20(4), pp. 423-443.

[5] Terzi, N. 2011. The impact of e-commerce on international trade and employment. Procedia-Social and Behavioral Sciences, 24, pp. 745-753.

[6] Awa, H. O., Ojiabo, O. U., \& Emecheta, B. C. 2015. Integrating TAM, TPB and TOE frameworks and expanding their characteristic constructs for e-commerce adoption by SMEs. Journal of Science \& Technology Policy Management, 6(1), pp. 76-94.

[7] Ramanathan, R. 2010. The moderating roles of risk and efficiency on the relationship between logistics performance and customer loyalty in e-commerce. Transportation Research Part E: Logistics and Transportation Review, 46(6), pp. 950-962.

[8] Soegoto, E. S., \& Eliana, E. (2018, August). E-Commerce and Business Social Media Today. In IOP Conference Series: Materials Science and Engineering, 407(1), p. 012034.

[9] Kongolo, M. 2010. Job creation versus job shedding and the role of SMEs in economic development. African journal of business management, 4(11), pp.2288-2295.

[10] Veit, D., Clemons, E., Benlian, A., Buxmann, P., Hess, T., Kundisch, D., ... \& Spann, M. 2014. Business models. Business \& Information Systems Engineering, 6(1), pp. 45-53. 